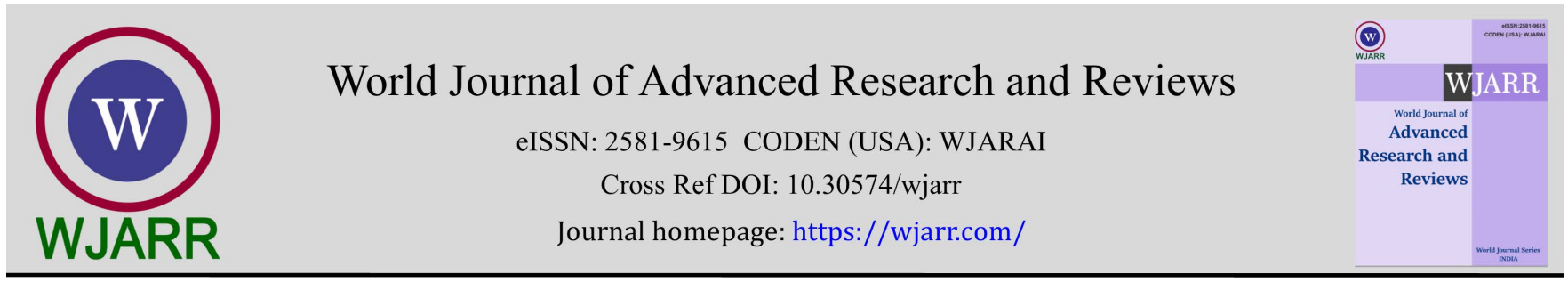

(REVIEW ARTICLE)

Check for updates

\title{
Depression, anxiety, and stress among general population due to covid-19 pandemic in several countries: A review article
}

\author{
Nadia Mardiana Hudan 1, Khisma Ekiyanti 1, Rozana Alfi Sania 1, Alpha Fardah Athiyyah 2, Dewi Ratna Sari 3 \\ and Maftuchah Rochmanti ${ }^{3, *}$ \\ ${ }^{1}$ Medical Program, Faculty of Medicine, Universitas Airlangga, Surabaya, Indonesia \\ ${ }^{2}$ Department of Child Health, Faculty of Medicine, Universitas Airlangga, Surabaya, Indonesia \\ 3 Department of Anatomy, Histology, and Pharmacology, Faculty of Medicine, Universitas Airlangga, Surabaya, Indonesia.
}

World Journal of Advanced Research and Reviews, 2022, 13(01), 391-397

Publication history: Received on 08 December 2021; revised on 09 January 2022; accepted on 11 January 2022

Article DOI: https://doi.org/10.30574/wjarr.2022.13.1.0037

\begin{abstract}
The existence of the COVID-19 virus has various impacts, one of which is a psychological impact. The studies that included were presented the results of depression, anxiety, and stress levels in the general population. The aim of this study is to establish the impact of COVID-19 pandemic on depression, anxiety, and stress in several countries worldwide. This study was a review based on Preferred Reporting Items for Systematic Review and Meta-Analysis (PRISMA). A systematic search was carried out to obtain relevant articles from PubMed and Google Scholar. The inclusion criteria in this study are using the cross-sectional method, assessing the mental health status of the general population during the COVID-19 pandemic, and using DASS-21 as the instrument. Whereas the exclusion criteria are the full text is not available, using a language other than English, and focusing on certain sample groups. In total, 3.547 publications were identified, of which 14 were included in this study. The various populations from Bahrain, Brazil, China, Philippines, India, Iran, Iraq, Italy, Pakistan, Portugal, Saudi Arabia, Serbia and Vietnam were found in this study. The different prevalence rates of depression, anxiety, and stress were obtained. Several factors that might influence the difference were gender, age, occupation, physical and mental health status from each individual. Gender, age, occupation, physical and mental health status impacted the prevalence of depression, anxiety, and stress symptoms.
\end{abstract}

Keywords: Depression; Anxiety; Stress; COVID-19; DASS-21; Mental Health

\section{Introduction}

A new coronavirus, called COVID-19, is an infectious disease that can spread among people. It originally appeared in Wuhan, China, in late December 2019 [1]. After February 25, 2020, a total of 81,109 have been laboratory-confirmed cases globally [33]. When COVID-19 was emerged as an epidemic, The World Health Organization (WHO) declared that it was a serious health problem. Due to the widespread of the disease that globally affecting many countries, it becomes a global pandemic since mid-March 2020 [2].

In response to this global health crisis, quarantine and lockdown were implemented by international health organizations and governments to suspend the spread of the virus. Further actions include staying at home, using face mask, social distancing, work and school from home, also applied in many countries [3]. In the past, quarantine has been an effective action used around the world in infectious disease outbreaks. However, it was an unfortunate experience for the residents. Movement restrictions, family or friend separation, fear of uncertain future, and restricted freedom are several factors that can have a negative impact on psychology [4]. This will have an effect on the psychological

\footnotetext{
${ }^{*}$ Corresponding author: Maftuchah Rochmanti

Department of Anatomy, Histology, and Pharmacology, Faculty of Medicine, Universitas Airlangga, Surabaya, Indonesia. 
condition of the general public. Various psychological problems and their consequences including depression, anxiety, stress, frustration in the face of uncertainty during the COVID-19 outbreak are important things to be noticed. In several observational studies, the overall prevalence of depression, anxiety, and distress was $31.4 \%, 31.9 \%$, and $41.1 \%$, respectively. A study showed that several stressors including longer quarantine duration, fear of getting infected, feeling bored, feeling lonely, feeling stress, confinement, false information, and losing money, have impact in worsening mental health [5].

This unpredicted situation related to the COVID-19 outbreak clearly shows that people are not well prepared on their mentality and how weak and powerless each person might be [6]. Consequently, it is critical to understand how far the impact of pandemic to mental health and other aspects of life [7]. Experts propose global research as a priority immediately, including monitoring levels of depression, anxiety, stress, and other mental health problems, to know the mechanisms and inform interventions [8]. Therefore, this study showed the data from several countries in the world about depression, anxiety, and stress as an effort to monitor the negative effect of the COVID-19 pandemic on mental health.

\section{Material and methods}

\subsection{Study Design}

This research is a review based on the Preferred Reporting Items for Systematic Review and Meta Analysis (PRISMA). A systematic search was carried out to obtain relevant articles from PubMed and Google Scholar. Keywords were entered into search engines in both databases i.e. (COVID-19) AND (Mental health) AND (DASS-21) AND (General population).

\subsection{Data Collection}

The title and abstract of each publication were screened for the relevance. Full-text articles are accessed for initial eligibility screening. Studies that are eligible to be included are if using the cross-sectional method, assessing the mental health status of the general population during the COVID-19 pandemic, and using DASS-21 as the instrument. Whereas the exclusion criteria are the full text is not available, using a language other than English, and focusing on certain sample groups.

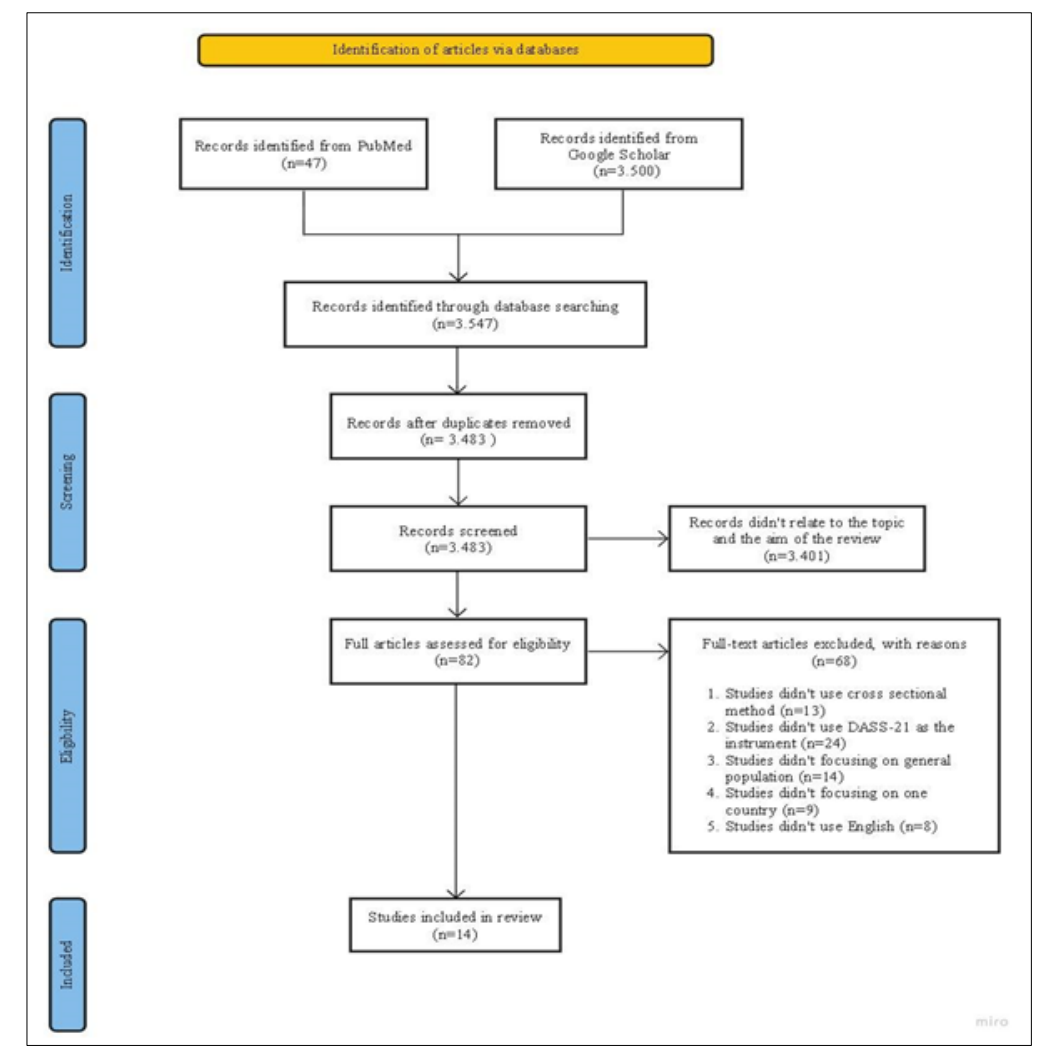

Figure 1 PRISMA Chart 


\section{Results and discussion}

Based on Table 1, it is known the authors' name, year of publication, study design, data collection methods, country, sample size, instruments, and the number of respondents experiencing depression, anxiety, and stress in each study.

Table 1 Included Studies in This Review Article

\begin{tabular}{|c|c|c|c|c|c|c|c|c|c|}
\hline \multirow[b]{2}{*}{ No } & \multirow[b]{2}{*}{ Authors (Year) } & \multirow{2}{*}{$\begin{array}{l}\text { Study } \\
\text { Design }\end{array}$} & \multirow{2}{*}{$\begin{array}{c}\text { Data } \\
\text { Collection } \\
\text { Methods }\end{array}$} & \multirow[b]{2}{*}{ Country } & \multirow{2}{*}{$\begin{array}{c}\text { Sample } \\
\text { Size }\end{array}$} & \multicolumn{4}{|c|}{ Results } \\
\hline & & & & & & & Depression & Anxiety & Stress \\
\hline \multirow{4}{*}{1} & \multirow{4}{*}{$\begin{array}{l}\text { A. AlSalman, H. } \\
\text { Mubarak, et al. } \\
(2020)\end{array}$} & \multirow{4}{*}{$\begin{array}{l}\text { Cross- } \\
\text { sectional }\end{array}$} & \multirow{4}{*}{$\begin{array}{l}\text { Online } \\
\text { Survey }\end{array}$} & \multirow{4}{*}{ Bahrain } & \multirow{4}{*}{1115} & Mild & $141(12.6 \%)$ & $48(4.3 \%)$ & $223(20 \%)$ \\
\hline & & & & & & Moderate & $126(11.3 \%$ & $94(8.4 \%)$ & $74(6.6 \%)$ \\
\hline & & & & & & Severe & $32(2.9 \%)$ & $36(3.2 \%)$ & $31(2.8 \%)$ \\
\hline & & & & & & $\begin{array}{l}\text { Extremely } \\
\text { Severe }\end{array}$ & $35(3.1 \%)$ & $25(2.3 \%)$ & $15(1.3 \%)$ \\
\hline \multirow{4}{*}{2} & \multirow{4}{*}{$\begin{array}{l}\text { A.A. Alkhamees et } \\
\text { al. }(2020)\end{array}$} & \multirow{4}{*}{$\begin{array}{l}\text { Cross- } \\
\text { sectional }\end{array}$} & \multirow{4}{*}{$\begin{array}{l}\text { Online } \\
\text { Survey }\end{array}$} & \multirow{4}{*}{$\begin{array}{l}\text { Saudi } \\
\text { Arabia }\end{array}$} & \multirow{4}{*}{1160} & Mild & $146(12.6 \%)$ & $68(5.9 \%)$ & $87(7.5 \%)$ \\
\hline & & & & & & Moderate & $138(11,9 \%)$ & $117(10.1 \%)$ & $100(8.6 \%)$ \\
\hline & & & & & & Severe & $77(6.6 \%)$ & $48(4.1 \%)$ & $93(8 \%)$ \\
\hline & & & & & & $\begin{array}{l}\text { Extremely } \\
\text { Severe }\end{array}$ & $114(9,8 \%)$ & $114(9.8 \%)$ & $66(5.7 \%)$ \\
\hline \multirow{4}{*}{3} & \multirow{4}{*}{$\begin{array}{l}\text { Wang, C., et al. } \\
(2020)\end{array}$} & & & & & Mild & $167(13.8 \%)$ & $91(7.5 \%)$ & $292(24.1 \%)$ \\
\hline & & & & & & Moderate & $148(12.2 \%)$ & $247(20.4 \%)$ & $66(5.5 \%)$ \\
\hline & & Cross- & Online & China & 1210 & Severe & & & \\
\hline & & & & & & $\begin{array}{l}\text { Extremely } \\
\text { Severe }\end{array}$ & $52(4.3 \%)$ & $102(8.4 \%)$ & $31(2.6 \%)$ \\
\hline & & & & & & Moderate & $1860(67.2 \%)$ & $2249(81.3 \%)$ & $2014(72.8 \%)$ \\
\hline 4 & $\begin{array}{l}\text { Mazza, C., et al. } \\
(2020)\end{array}$ & $\begin{array}{l}\text { Cross- } \\
\text { sectional }\end{array}$ & $\begin{array}{l}\text { Online } \\
\text { Survey }\end{array}$ & Italia & 2766 & Severe & $470(17 \%)$ & $198(7.2 \%)$ & $404(14.6 \%)$ \\
\hline & & & & & & $\begin{array}{l}\text { Extremely } \\
\text { Severe }\end{array}$ & $436(15.8 \%)$ & $319(11.5 \%)$ & $348(12.6 \%)$ \\
\hline & & & & & & Mild & $224(11.9 \%)$ & $181(9.6 \%)$ & $496(26.4 \%)$ \\
\hline & & & & & & Moderate & $239(12.7 \%)$ & $333(17.7 \%)$ & $179(9.5 \%)$ \\
\hline 5 & $\begin{array}{l}\text { Tee, M. L., et al. } \\
(2020)\end{array}$ & $\begin{array}{l}\text { Cross- } \\
\text { sectional }\end{array}$ & $\begin{array}{l}\text { Online } \\
\text { Survey }\end{array}$ & Filipina & 1879 & $\begin{array}{l}\text { Severe } \\
\text { Extrem ely } \\
\text { Severe }\end{array}$ & $78(4.2 \%)$ & $208(11.1 \%)$ & $73(3.9 \%)$ \\
\hline 6 & Verma S, Mishra & Cross- & Online & India & 354 & Moderate & $25 \%$ & $28 \%$ & $11.6 \%$ \\
\hline $0^{\circ}$ & A. $(2020)$ & sectional & Survey & India & 334 & Severe & $25 \%$ & $28 \%$ & $11.0 \%$ \\
\hline & & & & & & Normal & $302(55.1 \%)$ & $290(52.9 \%)$ & $452(82.5 \%)$ \\
\hline & & & & & & Mild & $96(17.5 \%)$ & $52(9.5 \%)$ & $44(8.0 \%)$ \\
\hline & NOthman. et al. & Cross- & Online & & & Moderate & $104(18.9 \%)$ & $144(26.3 \%)$ & $40(7.3 \%)$ \\
\hline 7 & $(2020)$ & sectional & Survey & Iraq & 548 & Severe & & & \\
\hline & & & & & & $\begin{array}{l}\text { Extremely } \\
\text { Severe }\end{array}$ & $46(8.4 \%)$ & $62(11.3 \%)$ & $12(2.2 \%)$ \\
\hline & & & & & & Mild & & & \\
\hline & & & & & & Moderate & & & \\
\hline 8 & et al. $(2020)$ & sectional & $\begin{array}{l}\text { Survey } \\
\text { Sunce }\end{array}$ & Brazil & 924 & Severe & $72 \%$ & $69 \%$ & $68 \%$ \\
\hline & & & & & & $\begin{array}{l}\text { Extremely } \\
\text { Severe }\end{array}$ & & & \\
\hline & & & & & & Normal & $613(58 \%)$ & $587(55,5 \%)$ & $370(35 \%)$ \\
\hline & & & & & & Mild & $138(13.1 \%)$ & $80(7.6 \%)$ & $284(26.9 \%)$ \\
\hline 0 & Vuj'ci'c, I., et al & Cross- & Online & Serhiz & 1057 & Moderate & $162(15.3 \%)$ & $178(16.8 \%)$ & $204(19.3 \%)$ \\
\hline$y$ & $(2021)$ & sectional & Survey & Serbia & & Severe & $75(7.1 \%)$ & $77(7.3 \%)$ & $128(12.1 \%)$ \\
\hline & & & & & & $\begin{array}{l}\text { Extremely } \\
\text { Severe }\end{array}$ & $69(6.5 \%)$ & $135(12.8 \%)$ & $71(6.7 \%)$ \\
\hline 10 & Hayat, $\mathrm{K}$, et al. & Cross- & Online & Pakistan & 1598 & Mild & $390(24.4 \%)$ & $490(30.7 \%)$ & $52(3,3 \%)$ \\
\hline & (2021) & sectional & Survey & & & Moderate & & & \\
\hline & & & & & & $\begin{array}{l}\text { Normal } \\
\text { Mild }\end{array}$ & $\frac{8409(79.9 \%)}{888(8.4 \%)}$ & $\begin{array}{l}7661(72.8 \%) \\
1082(10.3 \%)\end{array}$ & $\frac{7430(70.6 \&)}{2508(23.8 \%)}$ \\
\hline 11 & Paulino, M., et al. & Cross- & Online & Portugal & 10520 & Moderate & $1117(10.6 \%)$ & $1131(10.7 \%)$ & $591(5.6 \%)$ \\
\hline & $(2021)$ & sectional & Survey & & & Severe & $115(1.1 \%)$ & $531(5 \%)$ & 0 \\
\hline & & & & & & $\begin{array}{l}\text { Extremely } \\
\text { Severe }\end{array}$ & 0 & $124(1.2 \%)$ & 0 \\
\hline & & & & & & Normal & $429(68.6 \%)$ & $377(60.3 \%)$ & $482(77.2 \%)$ \\
\hline & & & & & & Mild & $85(13.6 \%)$ & $56(9.0 \%)$ & $53(8.5 \%)$ \\
\hline & Mautong, H., et al. & Cross- & Online & & & Moderate & $73(11.7 \%)$ & $118(18.9 \%)$ & $52(8.3 \%)$ \\
\hline 12 & $(2021)$ & sectional & Survey & Ecuador & 626 & Severe & $19(3.0 \%)$ & $35(5.6 \%)$ & $32(5.1 \%)$ \\
\hline & & & & & & $\begin{array}{l}\text { Extremely } \\
\text { Severe }\end{array}$ & $19(3.0 \%)$ & $39(6.2 \%)$ & $5(0.8 \%)$ \\
\hline
\end{tabular}




\begin{tabular}{|c|c|c|c|c|c|c|c|c|c|}
\hline \multirow[b]{2}{*}{ No } & \multirow[b]{2}{*}{ Authors (Year) } & \multirow{2}{*}{$\begin{array}{l}\text { Study } \\
\text { Design }\end{array}$} & \multirow{2}{*}{$\begin{array}{c}\text { Data } \\
\text { Collection } \\
\text { Methods }\end{array}$} & \multirow[b]{2}{*}{ Country } & \multirow{2}{*}{$\begin{array}{l}\text { Sample } \\
\text { Size }\end{array}$} & \multicolumn{4}{|c|}{ Results } \\
\hline & & & & & & & Depression & Anxiety & Stress \\
\hline \multirow{4}{*}{13} & \multirow{4}{*}{$\begin{array}{l}\text { Mohammadi, S. } \\
\text { M., et al. (2020) }\end{array}$} & \multirow{4}{*}{$\begin{array}{l}\text { Cross- } \\
\text { sectional }\end{array}$} & \multirow{4}{*}{$\begin{array}{l}\text { Online } \\
\text { Survey }\end{array}$} & \multirow{4}{*}{ Iran } & \multirow{4}{*}{241} & Mild & 0 & 0 & $5(2.1 \%)$ \\
\hline & & & & & & Moderate & $25(10.4 \%)$ & 0 & $106(44 \%)$ \\
\hline & & & & & & Severe & $124(51.5 \%)$ & $10(4.1 \%)$ & $118(49 \%)$ \\
\hline & & & & & & $\begin{array}{l}\text { Extremely } \\
\text { Severe }\end{array}$ & $92(38.2 \%)$ & $231(95.9 \%)$ & $12(5 \%)$ \\
\hline \multirow{4}{*}{14} & \multirow{4}{*}{$\begin{array}{l}\text { Duong, K. N. C.,et } \\
\text { al. (2020) }\end{array}$} & \multirow{4}{*}{$\begin{array}{l}\text { Cross- } \\
\text { sectional }\end{array}$} & \multirow{4}{*}{$\begin{array}{l}\text { Online } \\
\text { Survey }\end{array}$} & \multirow{4}{*}{ Vietnam } & \multirow{4}{*}{1385} & Mild & \multirow{4}{*}{$325(23.5 \%)$} & \multirow{4}{*}{$195(14.1 \%)$} & \multirow{4}{*}{$309(22.3 \%)$} \\
\hline & & & & & & Moderate & & & \\
\hline & & & & & & Severe & & & \\
\hline & & & & & & $\begin{array}{l}\text { Extremely } \\
\text { Severe }\end{array}$ & & & \\
\hline
\end{tabular}

This study shows an outline of mental health conditions among general population during the COVID-19 pandemic. Studies that included are from Bahrain, Brazil, China, Ecuador, Philippines, India, Iran, Iraq, Italy, Pakistan, Portugal, Saudi Arabia, Serbia, and Vietnam. The study used a cross sectional method with the DASS-21 instrument which was distributed online. From all studies in related countries, there are differences in the conditions and regulations applied. For example, the lockdowns implemented in China, India, Ecuador, Vietnam, and Saudi Arabia, as well as the quarantines imposed by Bahrain, China, Italy, the Philippines, and Vietnam. These policy differences have an influence on the rates of depression, anxiety, and stress in people in each country. Another country that has imposed a lockdown is Iran. There, the prevalence of depression and anxiety at an extremely severe level is 92 people (38.2\%) and 231 people (95.9\%), which is the largest number among studies in related countries [9]. Meanwhile, the highest prevalence of stress at the extremely severe level was found in a study in Italy of 384 people (12.6\%) [10].

This study also describes the factors that influence the prevalence of depression, anxiety, and stress in each country of origin of the study. These factors were gender, age, occupation, history of physical and mental health, and lifestyle during the COVID-19 pandemic. In gender, women tend to get mental disorder symptoms like depression, anxiety, and stress, as reported on the study in Bahrain [11], Saudi Arabia [12], China [13], Italy [10], Philippines [14], Brazil [15], Portugal [16], and Ecuador [17]. Other studies have shown that women have different neurobiological responses, self-concepts and coping styles when exposed to stress, and this is the basis for higher rates of psychological distress. This is because women have a greater response to the problems they face when compared to men $[18,19]$.

Young age is one of the factors that can influence depression, anxiety, and stress during a pandemic, as in the research we mentioned $[14,15,17]$. This is suitable with earlier research which states that there is an inverse relationship between age and levels of depression, anxiety, and stress. A possible reason could be that younger individuals are more likely to pay attention to the negative effect of the pandemic on the economics condition and employment in the future $[13,20]$. In addition, news broadcasts about COVID-19 which are mostly disappointing and frustrating are also affecting the mental health of young individuals as they have greater access to information on social media [21].

Students reported greater psychological impact and symptoms of depression, anxiety and stress than those who worked. Contributing factors include routine daily life, academic delays, and possibly reduced social support [22]. This is also due to the uncertainty which surround the methods utilized to continue the educational process following campus and school closures [12]. The potential negative impact on academic progress can also have a negative impact on students' mental health. Therefore, school and campus learning changed to an online method. This can be an alternative that supports them to gain knowledge from school and campus during the COVID-19 pandemic [13]. According to another study, work could also be a preventative measure for mental health during a pandemic [23]. Those who work from home, on the other hand, are more likely to be depressed than those who work in the office. This may have to do with their lack of social connections and a lot of distraction from pandemic-related news, which can increase their depression [24].

In the middle of a pandemic, health workers are at the forefront. Among the issues they face are long working hours, exhaustion, infection risk, a lack of personal protective equipment, loneliness, and risk of isolation from their family. They are at a high risk of having adverse mental health consequences. This is in accordance with the findings of a study in Saudi Arabia [12], which reported that someone who worked as a health worker had a higher score of depression and stress. Likewise, if someone has family members who work as health workers, they tend to have higher depression, anxiety and stress scores.

Respondents who rated their health badly has a larger psychological effect and lower mental health than those who considered their health well. Headache, sore throat, and muscle discomfort were the most commonly reported physical 
complaints. Those with symptoms had a worse psychological state than those who did not have symptoms [14]. During the COVID-19 outbreaks in mainland China, another study found something similar $[13,25]$. This could be due to the fact that the novel coronavirus has been proven to be more aggressive in patients with comorbidities and declining health, which could lead to increase the psychological stress and anxiety [26]. People with mental illnesses are more vulnerable to experiencing stress than the general public, thus such breakouts might cause relapses or even exacerbate existing psychological problems [27].

As the COVID-19 pandemic proceeds, our findings will benefit people by providing some knowledge and recommendations on mental health during the pandemic. First, for early physical and psychological intervention, medical experts must identify the risk factor based on socio-demographic data [13]. Second, in order to mitigate the impact of false information, the government and health authorities must disseminate the correct information regarding COVID-19 to the general public [28]. Third, the general public should be more aware about health protocols related to COVID-19 as the government recommendation, such as wearing masks both in health and illness, washing hands, not sharing utensils, and others. These preventive actions can have a positive impact on psychological responses because they can give confidence to themself and those around during the COVID-19 pandemic [13].

\section{Conclusion}

Depression, anxiety, and stress symptoms were reported in all related studies. Gender, age, occupation, physical and mental health status impacted the prevalence. Therefore, a combination of government policies and public awareness is needed in order to reduce the risk of virus transmission and minimize the psychological impact.

\section{Compliance with ethical standards}

\section{Acknowledgments}

This research was supported by the Faculty of Medicine, Universitas Airlangga. Also special regard and thanks were given to the lecturers and all those who contributed in this study.

\section{Disclosure of conflict of interest}

The authors declare that there is no conflict of interest that would affect the finding of this study.

\section{References}

[1] WHO. Pneumonia of unknown cause-China: World Health Organization. 2020.

[2] Cucinotta D, Vanelli M. WHO declares COVID-19 a pandemic. Acta bio-medica: Atenei Parmensis. 2020; 91(1): 157-60.

[3] Bedford J, Enria D, Giesecke J, Heymann DL, Ihekweazu C, Kobinger G, et al. COVID-19: towards controlling of a pandemic. The Lancet. 2020; 395(10229): 1015-8.

[4] Brooks SK, Webster RK, Smith LE, Woodland L, Wessely S, Greenberg N, et al. The psychological impact of quarantine and how to reduce it: rapid review of the evidence. The Lancet. 2020; 395(10227).

[5] Serafini G, Parmigiani B, Amerio A, Aguglia A, Sher L, Amore M. The psychological impact of COVID19 on the mental health in the general population. QJM: An International Journal of Medicine. 2020; 113(8).

[6] Torales J, O'Higgins M, Castaldelli-Maia JM, Ventriglio A. The outbreak of COVID-19 coronavirus and its impact on global mental health. International Journal of Social Psychiatry. 2020; 66(4): 317-320.

[7] Davico C, Ghiggia A, Marcotulli D, Ricci F, Amianto F, Vitiello B. Psychological Impact of the COVID-19 Pandemic on Adults and Their Children in Italy. Frontiers in Psychiatry. 2020; 12.

[8] Holmes EA, O'Connor RC, Perry VH, Tracey I, Wessely S, Arseneault L, Bullmore E. Multidisciplinary research priorities for the COVID-19 pandemic: a call for action for mental health science. The Lancet Psychiatry. 2020; 7(6): 547-560.

[9] Mohammadi SM, Ashtari S, Khosh Fetrat M. The psychological impact of COVID-19 pandemic on mental health of Iranian population. International Journal of Travel Medicine and Global Health. 2020; 9(1): 19-24. 
[10] Mazza C, Ricci E, Biondi S, Colasanti M, Ferracuti S, Napoli C, Roma P. A nationwide survey of psychological distress among Italian people during the COVID-19 pandemic: immediate psychological responses and associated factors. International Journal of Environmental Research and Public Health. 2020; 17(9): 3165.

[11] AlSalman A, Mubarak H, Aljabal M, Abdulnabi M, Ishaq A, Yusuf A, Jahrami H. The psychological impact of COVID19 Pandemic on the population of Bahrain. Acta Bio Medica: Atenei Parmensis. 2020; 91(4).

[12] Alkhamees AA, Alrashed SA, Alzunaydi AA, Almohimeed AS, Aljohani MS. The psychological impact of COVID-19 pandemic on the general population of Saudi Arabia. Comprehensive Psychiatry. 2020; 102: 152192.

[13] Wang C, Pan R, Wan X, Tan Y, Xu L, Ho CS, Ho RC. Immediate psychological responses and associated factors during the initial stage of the 2019 coronavirus disease (COVID-19) epidemic among the general population in China. International Journal of Environmental Research and Public Health. 2020; 17(5): 1729.

[14] Tee ML, Tee CA, Anlacan JP, Aligam KJG, Reyes PWC, Kuruchittham V, Ho RC. Psychological impact of COVID-19 pandemic in the Philippines. Journal of Affective Disorders. 2020; 277: 379-391.

[15] Ferreira DCS, Oliveira WL, Costa Delabrida ZN, Faro A, Cerqueira-Santos E. Intolerance of uncertainty and mental health in Brazil during the Covid-19 pandemic. Suma Psicológica. 2020; 27(1): 62-69.

[16] Paulino M, Dumas-Diniz R, Brissos S, Brites R, Alho L, Simões MR, Silva CF. COVID-19 in Portugal: exploring the immediate psychological impact on the general population. Psychology, Health \& Medicine. 2021; 26(1): 44-55.

[17] Mautong H, Gallardo-Rumbea JA, Alvarado-Villa GE, Fernández-Cadena JC, Andrade-Molina D, Orellana-Román, $\mathrm{CE}$, Cherrez-Ojeda I. Assessment of depression, anxiety and stress levels in the Ecuadorian general population during social isolation due to the COVID-19 outbreak: a cross-sectional study. BMC Psychiatry. 2021; 21(1): 115.

[18] Abate KH. Gender disparity in prevalence of depression among patient population: a systematic review. Ethiopian Journal of Health Sciences. 2013; 23(3): 283-288.

[19] Eid RS, Gobinath AR, Galea, LA. Sex differences in depression: Insights from clinical and preclinical studies. Progress in Neurobiology. 2019; 176: 86-102.

[20] Caqueo-Urízar A, Urzúa, A, Aragón-Caqueo D, Charles CH, El-Khatib Z, Otu A, Yaya S. Mental health and the COVID19 pandemic in Chile. Psychology Trauma: Theory, Research, Practice, and Policy. 2020; 12(5): 521-523.

[21] Moghanibashi-Mansourieh, A. Assessing the anxiety level of Iranian general population during COVID-19 outbreak. Asian Journal of Psychiatry. 2020; 51.

[22] Cao W, Fang Z, Hou G, Han M, Xu X, Dong J, Zheng J. The psychological impact of the COVID-19 epidemic on college students in China. Psychiatry Research. 2020; 287: 112934.

[23] Shi L, Lu Z, Que J, Huang X, Liu L, Ran M, Gong Y, Yuan K, Yan W, Sun Y, Shi J, Bao Y, Lu L. Prevalence of and Risk Factors Associated With Mental Health Symptoms Among the General Population in China During the Coronavirus Disease 2019 Pandemic. JAMA Netw Open. 2020; 3(7).

[24] Tran PB, Hensing G, Wingfield T, Atkins S, Annerstedt KS, Kazibwe J, Tomeny E, Biermann 0, Thorpe J, Forse R, Lönnroth K. Income security during public health emergencies: the COVID-19 poverty trap in Vietnam. BMJ Global Health. 2020; 5(6).

[25] Kang L, Li Y, Hu S, Chen M, Yang C, Yang BX, Liu Z. The mental health of medical workers in Wuhan, China dealing with the 2019 novel coronavirus. The Lancet Psychiatry. 2020; 7(3).

[26] Wang D, Hu B, Hu C, Zhu F, Liu X, Zhang J, Peng Z. Clinical characteristics of 138 hospitalized patients with 2019 novel coronavirus-infected pneumonia in Wuhan, China. JAMA. 2020; 323(11): 1061-1069.

[27] Yao H, Chen JH, Xu YF. Patients with mental health disorders in the COVID-19 epidemic. The Lancet Psychiatry. 2020; 7(4).

[28] Rubin GJ, Wessely S. The psychological effects of quarantining a city. The BMJ. 2020.

[29] Verma S, Mishra A. Depression, anxiety, and stress and socio-demographic correlates among general Indian public during COVID-19. International Journal of Social Psychiatry. 2020; 66(8): 756-762.

[30] Othman N, Kamal NM. Depression, anxiety, and stress in the time of COVID-19 pandemic in Kurdistan region, Iraq. Kurdistan Journal of Applied Research. 2020; 37-44. 
[31] Hayat K, Haq M, Wang W, Khan FU, Rehman AU, Rasool M, Fang Y. Impact of the COVID-19 outbreak on mental health status and associated factors among general population: a cross-sectional study from Pakistan. Psychology, Health \& Medicine. 2021; 1-15.

[32] Vujčić I, Safiye T, Milikić B, Popović E, Dubljanin D, Dubljanin E, Čabarkapa M. Coronavirus Disease 2019 (COVID19) Epidemic and Mental Health Status in the General Adult Population of Serbia: A Cross-Sectional Study. International Journal of Environmental Research and Public Health. 2021; 18(4): 1957.

[33] Duong KNC, Le Bao TN, Nguyen PTL, Van TV, Lam TP, Gia AP, Van BV. Psychological impacts of COVID-19 during the first nationwide lockdown in Vietnam: web-based, cross-sectional survey study. JMIR formative research. 2020; 4(12). 